\title{
Strategies for revegetation of disturbed gravel areas in climate stressed subarctic environments with special reference to Churchill, Manitoba, Canada: a literature review
}

\author{
Nicole Firlotte ${ }^{1}$, Richard J. Staniforth ${ }^{2}$ \\ ${ }^{1}$ Department of Botany, University of Manitoba, Winnipeg, Manitoba, Canada R3T 2N2 \\ ${ }^{2}$ Department of Biology, University of Winnipeg, 515 Portage Ave., Winnipeg, Manitoba, Canada R3B 2E9
}

\begin{abstract}
In the vicinity of Churchill, Manitoba, Canada, dry heath tundra is restricted to elevated gravel deposits such as beach ridges and eskers. These sites have been utilized for gravel excavation and extraction as well as for building and road construction. Vast areas of open gravel resulting from human activities scar the landscape and reduce the amount of undisturbed dry heath tundra. When left alone these gravel areas may remain devoid of vegetation for many decades due to the severity of the climate. Nothing has been done to restore them to their pre-disturbance vegetation cover. Their soils are characterized by low nutrient availability, poor moisture retention capabilities and limited seed banks. The current paper reviews literature regarding manipulation of chemical and physical properties of gravel substrates in order to facilitate the development of cover by native plants. A planned revegetation project is presented. This project would provide ecological and aesthetic benefits as well as enhance conservation and tourism in the area.
\end{abstract}

KEY WORDS: Revegetation · Tundra $\cdot$ Gravel $\cdot$ Colonization

\section{INTRODUCTION}

Churchill, Manitoba, Canada $\left(58^{\circ} 47^{\prime} \mathrm{N}, 94^{\circ} 11^{\prime} \mathrm{W}\right)$ is an easily accessible community in the High Subarctic and has been greatly affected by human activity. European settlement began in the 18th century with the building of Fort Prince of Wales, continuing with construction of an army base, rocket launch and residential and commercial properties to the present day (Hochbaum 1970, Walker 1970). Usually gravel was required for the foundations of buildings and for protecting the underlying permafrost (Sugden 1982, Bishop \& Chapin 1989). Gravel has been excavated from ancient beach ridges and from eskers in the vicinity of Churchill. This quarrying has caused considerable environmental damage and yet nothing has been done to alleviate it.

Gravel excavation required removal of overlying soil and vegetation ('the overburden') to expose the underlying gravel and allow assessment of its quality and quantity. The overburden was frequently burned or, more often, left as a heap adjacent to the open pit.

Exposed gravel in the open pits when combined with the severity of the subarctic climate provides a severe habitat for colonization by plants. In addition to climatic factors, other factors which limit colonization may include: soil moisture, nutrient supply, absence of organic particles or finer-grained mineral particles in the soil and an inadequate seed bank or seed rain (Wilson 1966, Miller 1982, Bradshaw 1983, 1984, Shaver \& Chapin 1986, Arnalds et al. 1987, Johnson 1987, Klokk \& Rønning 1987, Runolfsson 1987, Svoboda \& Henry 1987, Bishop \& Chapin 1989, Kohn \& Stasovski 1990, Salonen 1990). Artificial modification of topography and/or changes to the substrate may make gravel pits more hospitable to colonizing vegetation invasion (Johnson 1987). 


\section{NUTRIENT AVAILABILITY AND FERTILIZER TREATMENTS}

Quantities of nitrogen and phosphorus are often limiting factors in arctic soils (Wilson 1966, Haag 1974, Miller 1982, Shaver \& Chapin 1986, Klokk \& Rønning 1987, Truett \& Kertell 1992). The application of NPK fertilizer to restore the nutrient balance in denuded sites has been undertaken in many studies. with positive results (Chapin \& Chapin 1980, Skriabin 1981, Gartner et al. 1983, McKendrick 1991. Schoenholtz et al. 1992). Chapin \& Chapin (1980) applied 2 different fertilizer combinations, a high nitrogen compound (20-10-10) and high phosphorus compound (8-32-16), at the rate of $444 \mathrm{~kg} \mathrm{ha}^{-1}$ to a vegetation-free organic mat in an Eriophorum vaginatum tundra community. Ten years after the initial disturbance and fertilizer application, a complete vegetation cover dominated by Carex sp. and E. vaginatum was established (Chapin \& Chapin 1980). Gartner et al. (1983) found that application of NPK fertilizer $\left(25 \mathrm{~g} \mathrm{~m}^{-2} \mathrm{~N}\right.$ as $\mathrm{NH}_{4} \mathrm{NO}_{3}, 25 \mathrm{~g} \mathrm{~m}^{-2} \mathrm{P}$ as $\mathrm{P}_{2} \mathrm{O}_{5}$ and $32 \mathrm{~g} \mathrm{~m}^{-2} \mathrm{~K}$ as $\mathrm{K}_{2} \mathrm{O}$ ) enhanced natural recovery by stimulating growth of Carex sp. and grass seedlings on disturbed tundra sites. Schoenholtz et al. (1992) applied inorganic $\mathrm{N}$ fertilizer temporarily (1 growing season). The result was improved herbaceous biomass on mined soils, which minimized erosion (Schoenholtz et al. 1992). Phosphorous fertilizer improved native grass invasion and seedling establishment on barren areas (McKendrick 1987). McKendrick (1987) found areas without phosphorous fertilizer treatment averaged $65 \%$ canopy cover while fertilized areas had $100 \%$ canopy cover following $10 \mathrm{yr}$ of recovery time. It has been found that natural recovery of vegetation on disturbed gravel sites continues in the absence of fertilizer application; however, the recovery rate was considerably slower than in treated areas (Chapin \& Chapin 1980, Skriabin 1981, McKendrick 1991).

\section{WINTER DROUGHT AND SNOW COVER MANIPULATION}

Snow cover may provide important protection and moisture for the colonizing vegetation (Carlsson \& Callaghan 1991, McKendrick 1991). Ice crystals and strong winds cause abrasion and desiccation of any plant parts which are exposed above the snow surface (Savile 1972, Miller 1982). Lack of spring moisture where snow cover is sparse may restrict colonizing vegetation (McKendrick 1987, Kohn \& Stasovski 1990). Restoration of vegetation may be enhanced by trapping snow on open gravel areas to protect the pioneer vegetation during winter. This may be done by utilizing snow fences on or adjacent to denuded areas.

Snow cover may protect plants from destruction caused by vehicle movements. The restriction of construction to the winter months may minimize damage to plant cover (Hayhoe \& Tarnocai 1993). The use of winter roads serves to protect vegetation and permafrost from damage due to heavy traffic (Adam \& Hernandez 1977).

\section{SOIL TEXTURE AND ORGANIC MATTER APPLICATIONS}

Removal of organic surface layers to facilitate gravel extraction is detrimental to future plant colonization in dry tundra sites. The lack of organic matter and fine soil particles results in an area with little moisture holding capability and low levels of available nitrogen and phosphorous (Runolfsson 1987, Bishop \& Chapin 1989). The replacement of the organic matter is a primary goal of restoration (Johnson 1987). Pioneer vegetation fosters the accumulation of dead biomass and leaf litter which will decay over time and provide nutrients to the area as well as increase moisture holding capacity (Savile 1972, Freedman et al. 1982, Chapin \& Shaver 1989, Chambers et al. 1990). Under natural circumstances primary colonizers of disturbed gravel areas are usually cushion- or mat-forming species, such as Dryas integrifolia. Plants with these growth forms are able to accumulate organic matter (McCarthy 1992). The natural accumulation of an organic layer in the soil is a slow process; therefore, its artificial enhancement would increase the rate of vegetation recovery and also reduce the risk of erosion (Cargill \& Chapin 1987).

Skaller (1981), Bradshaw (1983), Gartner et al. (1983) and Street (1985) have shown that damage due to quarrying often can be reduced by stockpiling and redistributing the overburden onto the excavation site or the pit when gravel excavation has ended. Such treatment would be least expensive if undertaken immediately after excavation while heavy earth equipment is on site. In arctic areas where the overburden has not been stockpiled complete reconstruction can be very costly (Bradshaw 1983). Application of mulch on gravel areas has been ineffective since wind effects can easily remove it with no vegetation to hold it in place (Chambers et al. 1990). Planting grass in strips to induce organic accumulation on the gravel area can enhance natural revegetation (Runolfsson 1987). Manipulation of the vegetation cover can be an economic alternative to complete soil replacement. 


\section{SEED AVAILABILITY AND ENHANCEMENT OF SEED APPLICATION}

It is crucial for the colonization of denuded gravel areas that propagules arrive at the site (Bradshaw 1983). Seed production in these areas is often limited due the large investment of energy required throughout the growing season (Urbanska \& Schültz 1986, Diemer \& Prock 1993). Though limited, seed production is largely determined by the length and quality of consecutive growing seasons, hence a series of harsh years may result in decreased seed yields (Archibold 1984). Colonization of barren areas such as old gravel pits usually relies on the presence and proximity of a nearby seed source (Fridriksson 1987) or a viable seed bank (Archibold 1984).

The availability of seeds is partly determined by the proximity and composition of surrounding vegetation (Bishop \& Chapin 1989, Salonen 1990). Gravel areas may become totally dependent on incoming seed rain because of the absence of an overlying organic mat and its seed bank (Cargill \& Chapin 1987). Undisturbed areas adjacent to open gravel pits can provide a seed source for natural recovery (Salonen \& Setälä 1992). Decreased seed availability can be alleviated in 2 ways: by applying fertilizer to adjacent undisturbed areas to increase their seed production and by applying seeds directly to affected areas.

Fertilizer has been used to successfully increase seed production in adjacent undisturbed areas, with the result that the seed rain has significantly increased into the disturbed site (Chapin \& Chapin 1980). Chapin \& Chapin (1980) found that flowering density in adjacent sites increased by $25 \%$ after application of phosphorus and potassium. This resulted in the release of over 1000 seeds $\mathrm{m}^{-2}$ and a germination rate of $50 \%$ (Chapin \& Chapin 1980).

Seeding a gravel area may improve the rate of revegetation (Hernandez 1974). Exotic plant species have been used to achieve an initial vegetation cover to prevent erosion during pipeline construction (Webber \& Ives 1978, Chapin \& Chapin 1980, Densmore \& Holmes 1987). The use of introduced southern species like Nugget Kentucky bluegrass are thought to have more negative than positive effects on these gravel pads (Cargill \& Chapin 1987, Younkin \& Martens 1987, Densmore 1992, Forbes 1992). Complete vegetation cover is reached very quickly but the invasion by native species is restricted by the thatch created when the southern species die (Younkin \& Martens 1987). Native species should be preferred since they are adapted to the local environment, unlike the introduced southern species (Skriabin 1981, Elliott et al. 1987, Johnson 1987).

Utilization of native arctic species in revegetation projects is increasing. Companies commercially pro- duce seeds and make them available to the public. As native arctic species are adapted to these zarsh climatic conditions it only makes good sense to use a genotype which has evolved in the area to return it to a natural community cover (Elliott et al. 1987).

\section{PROPOSED RESTORATION STRATEGIES FOR THE CHURCHILL AREA}

In the Churchill area, revegetation of disturbed gravel areas would provide ecological and aesthetic benefits and enhance tourism and conservation. In an attempt to examine these denuded areas and the contributing environmental limitations inhibiting restoration, a research project is currently under way, with the following 4 objectives

(1) To produce a map of damaged areas in the Cape Churchill region. This will allow a quantitative estimation of disturbance in dry tundra areas.

(2) To determine the sequence of natural succession toward the climax dry tundra community and its rate from the initial disturbance.

(3) To set up permanent study sites in gravel quarries to attempt different revegetation strategies.

(4) To derive from data a ranking scheme of plants which can then be utilized in selecting appropriate species for the restoration of damaged dry tundra areas.

A more complete understanding of the natural processes occurring on disturbed dry tundra and the extent of damage will allow for the implementation of an appropriate restoration strategy for the area. Indeed this is only the beginning of restoring the gravel areas in the Churchill region.

Acknowledgements. We thank K. Burke, C. Paddock, L. Lee, D. Boudreau, C. Schreader and the Churchill Northern Studies Center for their logistical support in Churchill. Thanks to the people of Churchill, the members of Canada Parks Service, and the Local Government District in Churchill for the information they provided which was helpful in completing this work. This project was funded by the Northern Studies Training Program. We also thank Dr Peter Scott for his encouragement in the completion of this paper

\section{LITERATURE CITED}

Adam KM, Hernandez H (1977) Snow and ice roads: ability to support traffic and effects on vegetation. Arctic $30(1)$ : $13-27$

Archibold OW (1984) A comparison of seed reserves in arctic, subarctic and alpine soils. Can Field-Nat 98(3):337-344

Arnalds O, Aradóttir AL, Thorsteinsson I (1987) The nature of denuded areas in Iceland. Arct alp Res 19(4):518-525

Bishop SC. Chapin FS III (1989) Patterns of natural revegetation on abandoned gravel pads in arctic Alaska. J appl Ecol 26:1073-1081 
Bradshaw AD (1983) The reconstruction of ecosystems. J appl Ecol 20:1-17

Bradshaw AD (1984) Ecological principles and land reclamation practice. Landscape Planning 11:35-48

Cargill SM, Chapin FS III (1987) Application of successional theory to tundra restoration: a review. Arct alp Res 19(4):366-372

Carlsson BA, Callaghan IV (1991) Positive plant interactions in tundra vegetation and the importance of shelter. $J$ Ecol 79:973-983

Chambers JC, MacMahon JA, Brown RW (1990) Alpine seedling establishment: the influence of disturbance type. Ecology 71(4):1323-1341

Chapin FS, Chapin MC (1980) Revegetation of an arctic disturbed site by native tundra species. $J$ appl Ecol 17: $449-456$

Chapin FS III, Shaver GR (1989) Differences in growth and nutrient use among arctic plant growth forms. Funct Ecol $3: 73-80$

Densmore RV (1992) Succession on an Alaskan tundra disturbance with and without assisted revegetation with grass. Arct alp Res 24(3):238-243

Densmore RV, Holmes KW (1987) Assisted revegetation in Denali National Park, Alaska, USA. Arct alp Res 19(4): $544-548$

Diemer M, Prock S (1993) Estimates of alpine seed bank size in two central European and one Scandinavian subarctic plant communities. Arct alp Res 25(3):194-200

Elliott CL, McKendrick JD, Helm D (1987) Plant biomass, cover, and survival of species used for stripmine reclamation in south-central Alaska, USA. Arct alp Res 19(4): $572-577$

Forbes BC (1992) Tundra disturbance studies, I: long-term effects of vehicles on species richness and biomass. Environ Conserv 19(1):48-58

Freedman B, Hill N, Svoboda J, Henry G (1982) Seed banks and seedling occurrence in a high Arctic oasis at Alexandria Fjord, Ellesmere Island, Canada. Can J Bot 60: $2112-2118$

Fridriksson S (1987) Plant colonization of a volcanic island, Surtsey, Iceland. Arct alp Res 19(4):425-431

Gartner BL, Chapin FS, Shaver GR (1983) Demographic patterns of seedling establishment and growth of native graminoids in an Alaskan tundra disturbance. J appl Ecol 20:965-980

Haag RW (1974) Nutrient limitations to plant production in two tundra communities. Can J Bot 52:103-116

Hayhoe $H$, Tarnocai C (1993) Effect of site disturbance in the soil thermal regime near Fort Simpson, Northwest Territories, Canada. Arct alp Res 25(1):37-44

Hernandez H (1974) Possible effects on vegetation of the proposed gas pipeline from Prudhoe Bay, Alaska and the Mackenzie Delta, to Alberta. In: Environmental impact assessment of the portion of the Mackenzie gas pipeline from Alaska to Alberta, Vol IV. Research reports, Environmental Protection Board, Winnipeg, Manitoba, p $37-68$

Hochbaum HA (1970) Churchill - pattern for the future? Paper No 29. In: Fuller WA, Kevan PG (eds) ICUN Publications New Series 16. Proceedings of the conference on productivity and conservation in northern circumpolar lands. Edmonton Alta. October 1969. International Union of Conservation of Nature and Natural Resources, Morges, Switzerland, p 269-271

Johnson LA (1987) Management of northern gravel sites for successful reclamation: a review. Arct alp Res 19(4): $530-536$
Klokk T, Rønning OI (1987) Revegetation experiments at NyÅlesund, Spitsbergen, Svalbard. Arct alp Res 19(4): $549-553$

Kohn LM. Stasovski E (1990) The mycorrhizal status of plants at Alexandria Fiord, Ellesmere Island, Canada, a high arctic site. Mycologia 82(1):23-35

McCarthy DP (1992) Dating with cushion plants: establishment of a Silene acaulis growth curve in the Canadian Rockies. Arct alp Res 24(1):50-55

McKendrick JD (1987) Plant succession on disturbed sites, north slope, Alaska, USA. Arct alp Res 19(4):554-565

McKendrick JD (1991) Arctic tundra rehabilitation - observations of progress and benefits to Alaska. Agroborealis 23(1):29-40

Miller PC (1982) Environmental and vegetational variation across a snow accumulation area in montane tundra in central Alaska. Holarct Ecol 5:85-98

Runolfsson S (1987) Land reclamation in Iceland. Arct alp Res 19(4):514-517

Salonen V (1990) Early plant succession in two abandoned cut-over peatland areas. Holarct Ecol 13:217-223

Salonen V, Setälä H (1992) Plant colonization of bare peat surface - relative importance of seed availability and soil. Ecography 15:199-204

Savile DHO (1972) Arctic adaptations in plants. Monograph No 6, Research Branch, Canada Department of Agriculture, Ottawa

Schoenholtz SH, Burger JB, Kreb RE (1992) Fertilizer and organic amendment effects on mine spoil properties and revegetation success. Soil Sci Soc Am J 56:1177-1184

Shaver GR, Chapin FS III (1986) Effect of fertilizer on production and biomass of tussock tundra, Alaska, USA. Arct alp Res 18(3):261-268

Skaller PM (1981) Vegetation management by minimal intervention: working with succession. Landscape Planning $8: 149-174$

Skriabin SZ (1981) Studying the revegetation of tundra landscapes affected by industrial activities in the northern Yenisey River area. Draft translation 760. Cold Region Research Engineering Laboratory

Street EA (1985) Evaluation procedures for restored land. Environ Geochem Health 7(2):56-63

Svoboda J, Henry GHR (1987) Succession in marginal arctic environments. Arct alp Res 19(4):373-384

Sugden D (1982) Arctic and Antarctic. A modern geographical synthesis. Barnes and Noble Books, Totowa, NJ

Truett JC, Kertell K (1992) Tundra disturbance and ecosystem production: implications for impact assessment. Environ Manage 16(4):485-494

Urbanska KM, Schültz S (1986) Reproduction by seed in alpine plants and revegetation research above timberline. Bot helv 96(1):43-60

Walker $J(1970)$ The influence of man on vegetation at Churchill. Paper No 28. In: Fuller WA, Kevan PG (eds) ICUN Publications New Series 16. Proceedings of the conference on productivity and conservation in northern circumpolar lands. Edmonton Alta. October 1969. International Union of Conservation of Nature and Natural Resources, Morges, Switzerland, p 266-269

Webber PJ, Ives JD (1978) Damage and recovery of tundra vegetation. Environmental conservation 5(3):1 1 1-182

Wilson W (1966) An analysis of plant growth and its control in arctic environments. Ann Bot 30(119):383-402

Younkin WE, Martens HE (1987) Long term success of seeded species and their influence on native species invasion at abandoned rig site A-01 Caribou Hills, NWT, Canada. Arct alp Res 19(4):566-571 